\title{
Insulin analogues versus human insulin in type 1 diabetes: direct and indirect meta-analyses of efficacy and safety
}

\author{
Andréia Cristina Conegero Sanches, Cassyano Januário Correr, Rafael Venson, Patrícia Rodrigues \\ Gonçalves, Mariana Martins Garcia, Mário Sérgio Piantavini, Roberto Pontarolo*
}

Pharmacy Department, Federal University of Paraná, Curitiba, PR, Brazil

\begin{abstract}
All patients with Diabetes Mellitus (DM) receive insulin therapy. In this study, we evaluated the efficacy, safety and tolerability of human insulin and insulin analogues. We performed a systematic review of the literature and a meta-analysis according to the Cochrane Collaboration methodology. In the absence of clinical studies comparing insulins, we performed a mixed treatment comparison to establish the differences between the active treatments. We included studies published from 1995 to 2010 . HbA1c results, episodes of hypoglycemia and nocturnal hypoglycemia data were extracted and analyzed. Thirty-five randomized clinical trials were selected after examining the abstract and a full text review. These studies included 4,206 patients who received long-acting insulin analogues and 5,733 patients who received short-acting insulin analogues. Pooled data regarding efficacy indicated no significant differences in HbAlc values between glargine or detemir (once daily) and NPH insulin. However, a twice-daily dose of detemir produced differences in HbA1c values that favored detemir $(-0.14 \%$ [ $95 \%$ CI: -0.21 to -0.08$] ; \mathrm{p}<0.0001 ; \mathrm{I}^{2}=0 \%$ ). Direct and indirect comparisons are consistent and show that there were no significant differences between human insulin and insulin analogues in efficacy or safety. Our results indicate that long- and short-acting insulin analogues offer few clinical advantages over conventional human insulin.
\end{abstract}

Uniterms: Insulins/meta-analysis. Diabetes mellitus/type 1. Insulin/treatment efficacy. Insulin/safety use.

Todos os pacientes com Diabetes Mellitus (DM) tipo 1 recebem insulina. Neste estudo, avaliaram-se eficácia, segurança e tolerabilidade de insulinas humanas e análogas. Realizou-se uma revisão sistemática e meta-análise, de acordo com o preconizado pela Colaboração Cochrane. Na ausência de estudos clínicos comparando insulinas entre si, realizaram-se meta-análises de comparações indiretas a fim de estabelecer diferenças entre tratamentos ativos. Incluíram-se estudos de 1995 a 2010. Resultados de HbA1c, episódios de hipoglicemia e hipoglicemia noturna foram extraídos e analisados. Após leitura de resumos e, posteriormente, de artigos na íntegra, selecionaram-se 35 ensaios clínicos randomizados, totalizando 4206 pacientes utilizando insulina análoga de longa duração e 5733 pacientes insulina análoga de curta duração. Os resultados não demonstraram diferença estatisticamente significativa para redução de HbA1c entre glargina e detemir (uma vez ao dia) comparados a NPH. No entanto, insulina detemir utilizada duas vezes ao dia reduz a HbA1c $(-0.14 \%$ [95\% CI: -0.21 to -0.08$]$; $\left.p<0.0001 ; \mathrm{I}^{2}=0 \%\right)$. Comparações diretas e indiretas indicam que não existem diferenças significativas na médica de redução de HbA1c, independente da posologia de detemir, sendo estes resultados de eficácia e segurança consistentes. Os resultados indicam que insulinas análogas de longa ou curta duração apresentam pequenas vantagens, quando comparadas às insulinas tradicionais. Ademais, não existem diferenças entre eficácia e segurança quando comparamos insulinas análogas entre si.

Unitermos: Insulinas/meta-análise. Diabetes mellitus tipo 1. Insulina/eficácia. Insulina/segurança no uso.

\footnotetext{
*Correspondence: R. Pontarolo. Departamento de Farmácia, Universidade Federal do Paraná. Av. Pref. Lothário Meissner, n.632 - Jardim Botânico, 80210-170 - Curitiba - PR, Brasil. E-mail: pontarolo@ufpr.br
} 


\section{INTRODUCTION}

Diabetes mellitus is associated with serious long-term complications and premature death (Singh et al., 2009). The Diabetes Control and Complications Trial (DCCT) and the UK Prospective Diabetes Study confirmed the benefits of improved glycemic control (DCCT, 1993; UKPDS, 1998). To implement intensive insulin therapy, a physiologic model of insulin replacement is applied to most patients with type 1 diabetes mellitus (Pieber et al., 1995).

There are many good insulin formulations; however, metabolic control in many patients remains unsatisfactory (Plank et al., 2005).

For many years, the most commonly used type of insulin that provided a basal insulin supply was NPH (Neutral Protamine de Hagedorn); however, it has been shown to frequently result in nocturnal hypoglycemia due to unintended plasma insulin peaks (Rosenstock et al., 2005). Injection of regular human insulin does not replicate the postprandial endogenous secretion of insulin. Insulin analogues are modified forms of human insulin that have been developed to address this limitation (Singh et al., 2009). Since 2000, long-acting insulin analogues have been available. They are progressively replacing NPH insulin as the preferred form of basal insulin for type 1 diabetes because of their favorable pharmacokinetics and pharmacodynamics, namely a less pronounced peak concentration and longer duration of action, which results in lower HbA1c levels and fewer episodes of hypoglycemia (Bolli et al., 2009a).

Unmodified human insulin hardly mimics the physiologic post-prandial insulin peak of non-diabetic people because there is a high tendency for it to aggregate as a hexamer at the injection site. Short-acting insulin analogues have reduced tendencies toward oligomerization, which allows them to be more quickly absorbed into the blood; as a consequence, they have faster onsets of action (Plank et al., 2005).

Numerous clinical trials have demonstrated the pharmacokinetic advantages of insulin analogues. However, a recent meta-analysis suggested that the rapidacting analogues provide only small advantages in terms of HbA1c (glycated hemoglobin or glycosylated hemoglobin) reductions and no advantages for hypoglycemia compared with unmodified human insulin (Gough, 2007). Although insulin analogues are commonly prescribed for the management of diabetes mellitus, there is uncertainty regarding their optimal use (Singh et al., 2009).

Systematic reviews of insulin analogues have been published previously (Brunelle et al., 1998; Siebenhofer A et al., 2004; Warren et al., 2004; Plank et al., 2005; Gough,
2007; Monami et al., 2009; Singh et al., 2009). However, through our comprehensive search of the literature, we did not encounter any reviews delving into the efficacy, safety and tolerability of both short- and long-acting insulin analogues for the management of type 1 diabetes in adults. Within this context, the aim of this work was to evaluate these characteristics of short- and long-acting insulin analogues in comparison with the conventional human insulins.

\section{METHODS}

We performed a systematic review of the literature and a meta-analysis that compared the efficacy and safety of various long-acting insulin analogues, Neutral Protamine Hagedorn (NPH) and regular human insulin in type 1 diabetic adults ( $\geq 18$ years). All studies used the same long-acting insulin for both treatments.

A systematic review of the literature was conducted in accordance with the methodology of the Cochrane Collaboration guidelines (Higgins et al., 2009). We performed a comprehensive search for randomized controlled trials using several combinations of keywords, including "glargine," "lantus," "detemir," "levemir," "aspart," "novorapid," "lispro," "humalog," "glulisine," "apidra," "type 1 diabetes," "insulin-dependent diabetes" and "random,"* in the following databases: Scopus, Medline, Cochrane Library, Lilacs and International Pharmaceutical Abstracts (IPA). The literature search was supplemented with a hand search of references and other systematic reviews that have already been published. The search included studies performed between January 1995 and December 2010 without language restriction.

\section{Selection and quality assessment of trials}

Two reviewers (A.S. and R.V.) independently selected the studies initially by reviewing the titles and abstracts. These studies included exclusively doubleblinded randomized controlled trials (RCTs) of adult patients with established type 1 diabetes who received a long-acting insulin analogue (glargine or detemir), a shortacting insulin analog (aspart, lispro or glulisine), NPH insulin (either alone or in combination with rapid-acting human insulin [regular]) or insulin analogues (lispro or aspart) for at least 4 weeks. We included detemir with a treatment regimen of once- or twice-daily. We excluded studies that used a crossover methodology.

Data extraction was performed by two independent authors (A.S. and C.C.) in accordance with the recommendations of the Cochrane Handbook for 
Systematic Reviews of Interventions (Higgins et al., 2009). Extracted data included study design, baseline characteristics, health intervention, drug regimen, concomitant treatments and outcomes. Any disagreement in data collection was resolved through consensus and with a third reviewer (R.V.) when necessary. The quality of each trial was evaluated using a method assessment tool published by Jadad et al. (1996).

\section{Outcomes}

Two major outcomes were obtained: efficacy, defined as a change $(\%)$ in $\mathrm{HbA} 1 \mathrm{c}$ concentration at the end of the study, and safety, including overall hypoglycemia episodes and nocturnal hypoglycemia episodes, as defined by the number of patients with at least one episode during the study for long-acting insulin or the number of patients with at least one episode during a month for short-acting insulin.

\section{Statistical analyses}

The efficacy results are described as the mean difference (MD) with an associated $95 \%$ confidence interval (CI) for the HbAlc changes at the end of the studies. For the safety results (hypoglycemia) and withdrawals (because of adverse events or a lack of efficacy), the odds ratio (OR) method was used with the associated $95 \% \mathrm{CI}$ of the event rates.

The data of the included studies were pooled across the trials using the random effect model (inverse variance method). Heterogeneity was evaluated by the inconsistency index $\left(\mathrm{I}^{2}\right)$. Values of $\mathrm{I}^{2}$ lower than $25 \%$ were considered low heterogeneity, whereas values of $25-50 \%$ were considered moderate to high heterogeneity. In metaanalyses that showed $\mathrm{I}^{2}>50 \%$ (high heterogeneity), several sensitivity analyses were performed to determine whether the study characteristics (including low methodological quality) and statistical methods could have influenced the results.

When it was not possible to perform meta-analyses of direct treatment comparisons, we used indirect comparisons to evaluate the relative efficacy between insulin analogues. Indirect treatment comparisons in metaanalyses can be analyzed by various methods according to the different networks applied, including star, ladder, closed-loop and partially closed-loop designs (Wells, 2009). We used the star design, as described by Bucher et al. (Bucher; Guyatt; Griffith Le; Walter, 1997), and adjusted the relative efficacy by the level of response to a common denominator (NPH or regular insulin).
Statistical analyses were conducted using the software Review Manager V.5.0 for Windows (Copenhagen - Denmark: The Nordic Cochrane Centre, The Cochrane Collaboration, 2011) and the Indirect Treatment Comparison Software Application by the ADDIS (Aggregate Data Drug Information System) V.1.6 (Groningen - Netherlands: University of Groningen, 2012). A p value less than 0.05 was considered to be statistically significant.

\section{RESULTS AND DISCUSSION}

\section{Systematic review of the literature}

We initially identified 635 citations for glargine vs. NPH, 416 citations for detemir vs. NPH and 187 citations for glargine and detemir, of which 601,397 and 183 , respectively, were excluded on the basis of the title or abstract. Two independent reviewers evaluated the remaining articles (see Figure 1).

\begin{tabular}{|c|c|}
\hline $\begin{array}{l}\text { Identified articles: glargine } \\
\text { (635), detemir (416), glargine vs } \\
\text { detemir (187), lispro (954), } \\
\text { aspart (681), glulisine (240) } \\
\text { glulisine and lispro (140), } \\
\text { glulisine and aspart (112), lispro } \\
\text { and aspart (696) }\end{array}$ & \\
\hline & $\begin{array}{l}\text { Excluded because of failure to } \\
\text { meet inclusion criteria: glargine } \\
\text { (601), detemir (397), glargine vs } \\
\text { detemir (183), lispro (948), } \\
\text { aspart (670), glulisine (237), } \\
\text { glulisine and lispro (137), } \\
\text { glulisine and aspart (111), lispro } \\
\text { and aspart (687) }\end{array}$ \\
\hline
\end{tabular}

Articles retrieved for detailed assessment: glargine (34), detemir (19), glargine vs detemir (4), lispro (6), aspart (11), glulisine (3), glulisine and lispro (3), glulisine and aspart (1), lispro and aspart (9)

Trial included: glargine (7), detemir (6), glargine vs detemir (2), lispro (4), aspart (7), glulisine (1), glulisine and lispro (1), glulisine and aspart (0), lispro and aspart (1)

FIGURE 1 - Flowchart of the selection of randomized controlled trials included in our systematic review of long- and short-acting insulin analogues.

The remaining 16 articles for long-acting insulin analogues (glargine vs. NPH, 7; detemir vs. NPH, 7; glargine vs detemir, 2) were included in our meta-analysis
Excluded because of failure to meet inclusion criteria: glargine (27), detemir (13), glargine vs detemir (2), lispro (3), aspart (4), glulisine (2), glulisine and lispro (2), glulisine and aspart (1), lispro and aspart (8) 
(Garg et al., 1995; Anderson Jr. et al., 1997; Ciofetta et al., 1999; Home, 2000; Raskin, Guthrie, et al., 2000; Raskin, Klaff et al., 2000; Ratner et al., 2000; Rosenstock et al., 2000; Bode, Strange, 2001; Tamas et al., 2001; Bode et al., 2002; Devries et al., 2003; Vague et al., 2003; Hermansen et al., 2004; Porcellati et al., 2004; Russell-Jones et al., 2004; Home et al., 2004; De Leeuw et al., 2005; Fulcher et al., 2005; Home et al., 2005; Pieber et al., 2005; Home et al., 2006; Pieber et al., 2007; Bartley et al., 2008; Heller et al., 2009; Bolli et al., 2009 b).

When we combined all of the studies, we counted 5,733 patients who received a short-acting insulin analog (aspart, lispro or glulisine). For lispro vs. regular, there were 954 patients; aspart vs. regular, 681; glulisine vs. regular, 240; glulisine vs. lispro, 140; glulisine vs. aspart, 112; lispro vs. aspart, 696. For all of the participants, the mean age was 39.2 years, and the mean body mass index (BMI) was 24.8. The number of patients in each study ranged from 57 to 747 . The durations of the trials ranged from 7 to 64 weeks. The studies that examined the effects of long-acting insulin included 4,771 patients who received long-acting or NPH insulin. For the participants in these studies, the mean BMI was 24.9. The number of patients in each study ranged from 57 to 747 . The trials included in the current meta-analysis had a mean duration of treatment of 26 weeks for glargine and 25 weeks for detemir. The durations of the trials ranged from 4 weeks to 12 months.

\section{Efficacy of long- and short-acting insulin analogues}

Forest plots showing the mean difference (MD) based on the change in $\mathrm{HbA} 1 \mathrm{c}$ values at the end of the studies in adults with type 1 diabetes receiving glargine or detemir versus NPH or aspart, lispro or glulisine versus regular insulin are represented in Figure 2.

Compared with NPH insulin, the use of insulin glargine did not result in significant differences in $\mathrm{HbA} 1 \mathrm{c}$ values (MD: $-0.04 \%$ [95\% CI: -0.12 to 0.05$] ; p=0.39$ ). There was a moderate degree of heterogeneity (43\%). Primary data for detemir, compared with NPH insulin, were pooled into two subgroups based on the treatment regimen of once- or twice-daily treatment. For the oncea-day regimen, no statistically significant differences were found that favored one particular treatment (MD: $-0.11 \%$ [ $95 \%$ CI: -0.32 to 0.11$] ; p=0.34$ ), but the results were inconsistent $\left(\mathrm{I}^{2}=71 \%\right)$ because of the low number of studies. For the twice-a-day regimen, the difference in $\mathrm{HbA} 1 \mathrm{c}$ values favored detemir (MD: $-0.14 \%$ [95\% CI: -0.21 to -0.01$\left.] ; \mathrm{p}<0.0001 ; \mathrm{I}^{2}=0 \%\right)$. The overall result of the meta-analysis favored detemir because of the low heterogeneity values. We found no significant differences in the mean change in $\mathrm{HbAlc}$ values when we directly compared glargine and detemir (2 studies). The MD, independent of the detemir treatment regimen, was $-0.07 \%$ (95\% CI: -0.19 to $\left.0.06 ; p=0.31 ; I^{2}=0 \%\right)$. It was not possible to perform a meta-analysis separately comparing once-daily or twice-daily glargine and detemir. A mixed treatment comparison of glargine and detemir (once- or twice-daily), adjusted for the level of response to NPH insulin, showed no significant difference in the mean change in the HbA1c value. The MD observed for both detemir regimens was $-0.12 \%$ [95\% CI: -0.03 to 0.20 ]. We found that aspart is more effective than regular insulin (MD: -0.13 [95\% CI: -0.17 to -0.09 ]; $\mathrm{p}<0.00001 \%$ ), with little variability between studies, as demonstrated by a heterogeneity value of $0 \%$. While inpatients treated with insulin lispro did not differ significantly $(\mathrm{p}=0.36$, MD: -0.08 [ $95 \%$ CI: -0.24 to 0.8 ]), the absence of heterogeneity

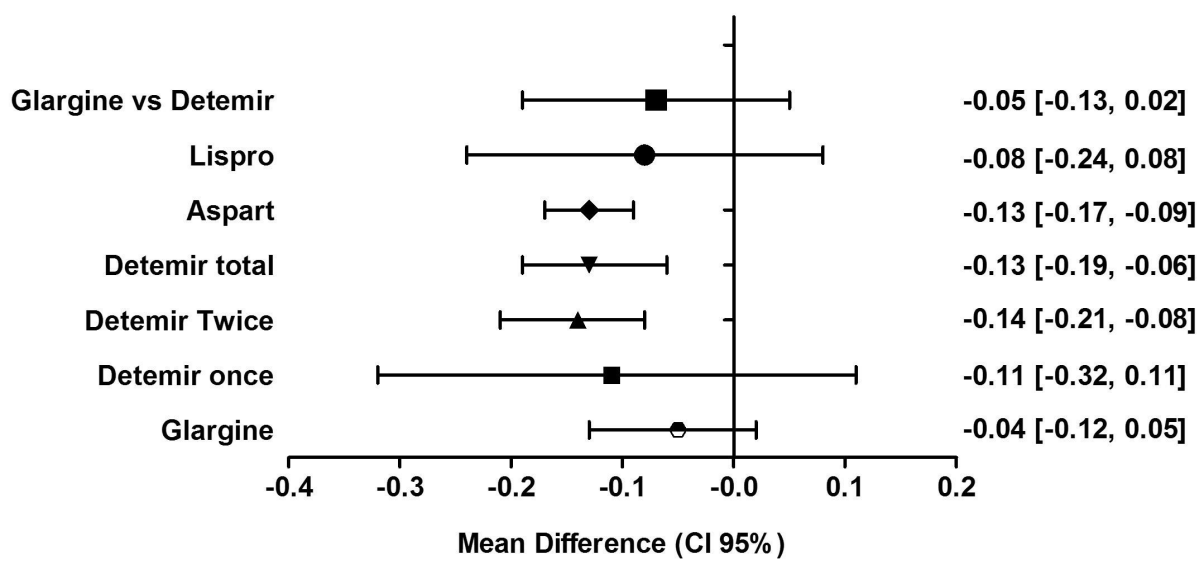

FIGURE 2 - Forest plots showing the MD based on the HbA1c changes at the end of the studies in adults with type 1 diabetes using the inverse variance method (random effect model). 
$(0 \%)$ was demonstrated by the sensitivity, robustness and regularity among the studies. The network of evidence surrounding comparisons of glargine, detemir and NPH insulin showed that there were no significant differences among treatments (glargine vs. NPH $[-0.07(-0.16 ; 0.03)]$, detemir vs. NPH $[-0.07(-0.16 ; 0.02)]$ and glargine vs. detemir $[-0.00(-0.11 ; 0.11)])$. The rank of probability to choose long-acting insulin shows that NPH is first $(87 \%)$, detemir is second (53\%) and glargine is third (46\%). The potential reduction scale factor was 1 , and these results are consistent.

In our systematic review, we only found one article comparing insulin glulisine versus regular insulin and one clinical trial comparing insulin aspart, glulisine and lispro. Therefore, we could not perform a meta-analysis of these comparisons. The results for $\mathrm{HbA} 1 \mathrm{c}$ reductions in these studies are presented in Table I.

We found small differences between treatments when we searched the various studies, and direct metaanalyses were performed to contribute to the analysis of this outcome.

$\mathrm{HbA} 1 \mathrm{C}$ reductions were analyzed using the ADDIS software, which performs network meta-analyses and portrays results graphically, as shown in Figures 3 A and B.

Among human rapid-acting insulin options, regular insulin is most likely to be the first choice for the treatment of type $1 \mathrm{DM}$, followed by the insulin analog glulisine, then lispro and finally aspart. Our results, which show small differences in the ability of similar rapid-acting insulin analogues and regular human insulin to lower

TABLE I - HbA1C reductions, SD and p values for the following comparisons: glulisine vs. regular insulin, glulisine vs. lispro and aspart vs. lispro

\begin{tabular}{llccc}
\hline Comparison & Author/year & Reduction HbA1C \pm SD & p value & \\
\hline Glulisine vs. Regular & Garg, 2005 & Glulisine & Regular & $\mathrm{P}=0.670$ \\
& & $* \mathrm{AM}$ & & \\
& & $-0.26 \pm 0.65$ & $-0.13 \pm 0.66$ & \\
& & $* * \mathrm{BM}$ & & \\
\hline Glulisine vs. Lispro & Kawamori, 2009 & $-0.11 \pm 0.65$ & $-0.13 \pm 0.66$ & \\
& & Glulisine & Regular & NA \\
\hline Aspart vs. Lispro & Bode, 2002 & $0.10 \pm 0,71$ & $0.03 \pm 0.58$ & NA \\
& & Aspart & Lispro & \\
\hline
\end{tabular}

* AF: after meal; ** BM: before meal; NA: not available

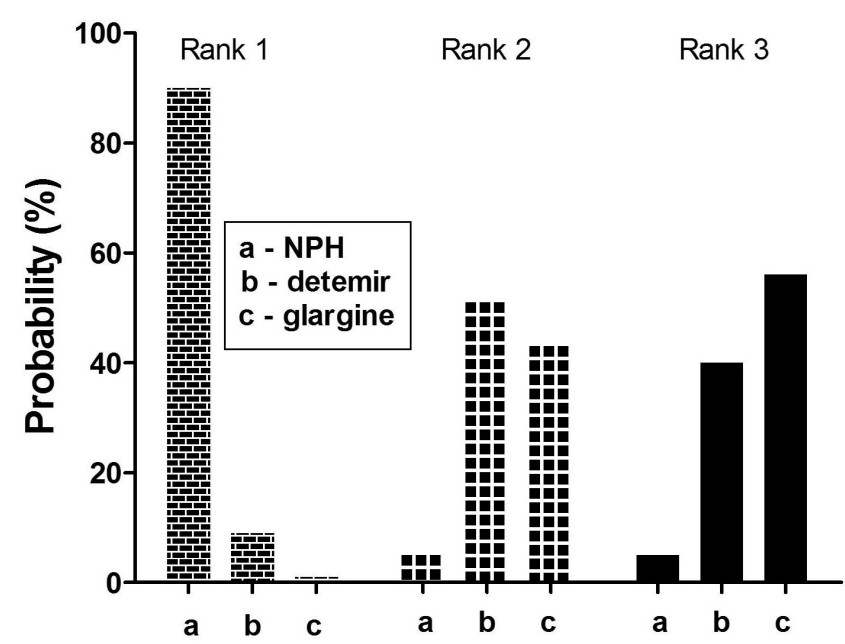

(A)

Rank

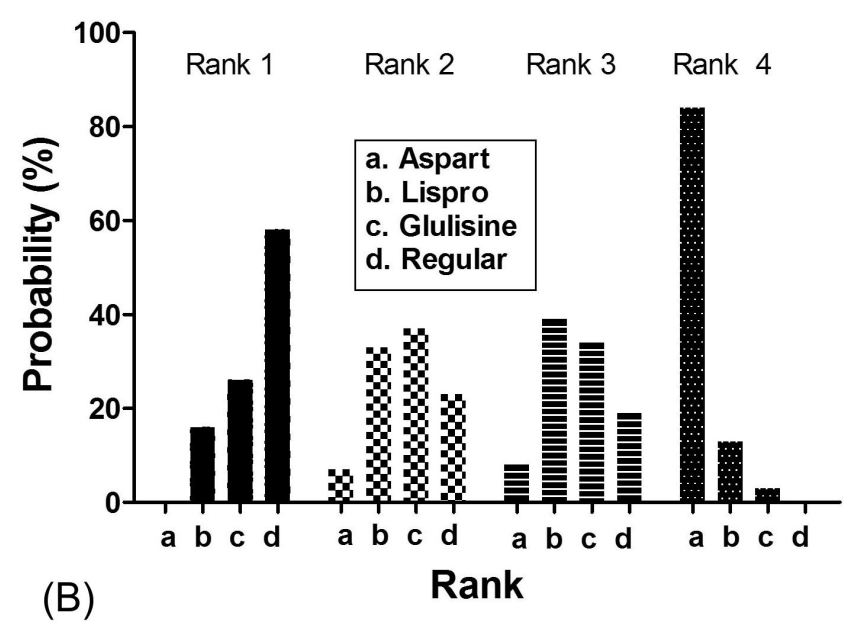

FIGURE 3 - The probability that long- (A) or rapid-acting (B) insulin analogues are the best choice for patients with type 1 diabetes mellitus. Rank 1 represents the insulin analog most likely to be the first choice for treatment of type 1 diabetes mellitus. 


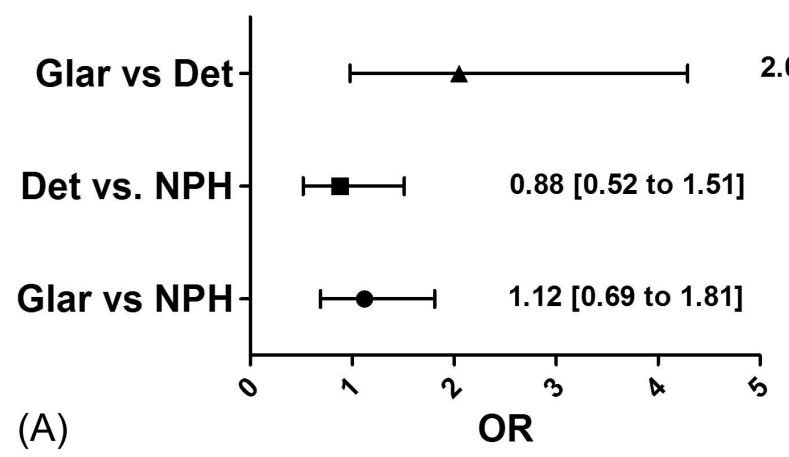

2.05 [0.98 to 4.29$]$

FIGURE 4 - Odds ratio for hypoglycemia (patients with any episode during the study) with insulin analogues, where A contains the meta-analysis of the safety of long-acting insulins and B contains the meta-analysis of the safety of short-acting insulin analogues. Legend: Glar, glargine; Det, Detemir; NPH, Human Insulin NPH.

$\mathrm{HbA1C}$ values, are in agreement with those that have been found by other authors (Jansson et al., 1998; Siebenhofer et al., 2004; Plank et al., 2005; Forst, Pfützner, 2007).

The results of the long- and short-acting insulin analogues are consistent, and direct and indirect comparisons did not reveal significant differences among human insulin and insulin analogues with regard to their ability to reduce $\mathrm{HbA} 1 \mathrm{C}$ values. Therefore, although there is a ranking system that can be used to choose the best option for insulin therapy, the differences in efficacy between them are small. These data are consistent with direct measurements that have already been published.

\section{Safety of long-acting insulin analogues}

The results detailing the safety of glargine, detemir and NPH insulin are shown in Figure 4 A. Figure 4 B shows the safety results of short-acting (lispro, aspart and regular) insulin types.

The hypoglycemia results were inconsistent for both insulin analogues (high $\mathrm{I}^{2}$ ). For glargine and $\mathrm{NPH}$, the mean percentages of participants reporting any hypoglycemia episode (74.4 vs. $74.1 \%$ ) were not different. The hypothetical exclusion of any trial did not change the outcomes. For detemir and NPH, we found similar results; the mean percentages of participants reporting any hypoglycemia episode were 79.2 and $81.5 \%$, respectively. The exclusion of one study (39) reduced the heterogeneity to $52 \%$ without significant changes to the results. This difference likely results from the high doses of detemir $(0.83 \mathrm{UI} / \mathrm{kg} /$ day $)$ and NPH insulin $(0.44 \mathrm{UI} / \mathrm{kg} /$ day $)$ in the study by Vague et al. in relation to the doses used in the other studies ( 0.31 to $0.44 \mathrm{UI} / \mathrm{kg} /$ day for detemir and 0.32 to $0.36 \mathrm{UI} / \mathrm{kg} /$ day for NPH). Safety, as measured by the number of patients with at least one hypoglycemic episode per month, was analyzed for short-acting insulin analogues. We observed no significant differences between insulin aspart and regular insulin, and the heterogeneity was $0 \%$. The same result was found when we compared insulin lispro with regular insulin; however, the clinical trial by Ciofetta et al. (Ciofetta et al., 1999) included only a small number of patients $(n=8)$ in both groups, thereby causing greater variability in the results. This variability resulted in moderate heterogeneity (38\%). Insulin glulisine compared with regular insulin was also not significantly different; however, for insulin glulisine, the meta-analysis was not performed because only one clinical trial was found with the correct inclusion criteria. A similar situation occurred when we compared insulin lispro with glulisine ( 3.93 vs. $3.86 ; p=0.1642$ ). In the only instance where both insulin aspart and lispro were compared, the authors (Bode et al., 2002) confirmed that hypoglycemic episodes per month were not significantly different between the treatments; however, there was less of these episodes for the group treated with insulin aspart $(3.9 \pm 4.2)$ compared with insulin lispro $(4.4 \pm 5.6)$ or regular insulin $(4.9 \pm 4.6)$.

\section{CONCLUSIONS}

Long- and short-acting insulins are used to compensate for a lack of insulin secretion in patients with type 1 diabetes. These patients use multiple daily injections or continuous subcutaneous insulin infusions to mimic the mealtime rapid-acting or basal insulin normally secreted by the pancreas (Bolli et al., 2009 a).

There were no significant differences in the changes in $\mathrm{HbA1c}$ values for glargine and detemir (once-daily) compared with NPH insulin and glargine versus detemir. Moreover, for the twice-daily detemir regimen, the differences in $\mathrm{HbA} 1 \mathrm{c}$ values favor detemir over NPH insulin. With regard to indirect comparisons of detemir and glargine, the two primary studies combined the efficacy 
data of once- or twice-daily detemir regimens and thus did not allow a separate meta-analysis of both regimens. In these cases, mixed treatment comparisons indicated no significant differences in the efficacy of once- or twice-daily detemir compared with once-daily glargine. Aspart is more effective when compared with regular insulin, but lispro and glulisine, which are also short-acting insulin analogues, are not more effective than human short-acting insulin.

Safety data based on clinical trials comparing glargine and detemir were similar with regard to patients with any hypoglycemia episode $(56.1 \%$ vs. $37.8 \%$; $\mathrm{p}=0.06$, respectively), without significant differences calculated by the risk ratio. There were no statistically significant differences among short-acting insulin treatments. In summary, these results indicate that there are only small differences in glycemic control and safety among human and insulin analogues (long- and short-acting).

\section{CONFLICTS OF INTEREST}

All authors declare that they do not have any conflicts of interest.

\section{ACKNOWLEDGMENTS}

The authors acknowledge the research support received from the Araucaria Foundation from the State of Parana, Brazil.

\section{REFERENCES}

ANDERSON JR., J.H.; BRUNELLE, R.L.; KOIVISTO, V.A.; TRAUTMANN, M.E.; VIGNATI, L.; DIMARCHI, R. Improved mealtime treatment of diabetes mellitus using an insulin analogue. Multicenter Insulin Lispro Study Group. Clin. Ther., v.19, n.1, p.62-72, 1997.

BARTLEY, P.C.; BOGOEV, M.; LARSEN, J.; PHILOTHEOU, A. Long-term efficacy and safety of insulin detemir compared to Neutral Protamine Hagedorn insulin in patients with Type 1 diabetes using a treat-to-target basal-bolus regimen with insulin aspart at meals: a 2-year, randomized, controlled trial. Diabetic Med., v.25, n.4, p.442-449, 2008.

BODE, B.; WEINSTEIN, R.; BELL, D.; MCGILL, J.; NADEAU, D.; RASKIN, P.; DAVIDSON, J.; HENRY, R.; HUANG, W.C.; REINHARDT, R.R. Comparison of insulin aspart with buffered regular insulin and insulin lispro in continuous subcutaneous insulin infusion: a randomized study in type 1 diabetes. Diabetes Care, v.25, n.3, p.439444, 2002.
BODE, B.W.; STRANGE, P. Efficacy, safety, and pump compatibility of insulin aspart used in continuous subcutaneous insulin infusion therapy in patients with type 1 diabetes. Diabetes Care, v.24, n.1, p.69-72, 2001.

BOLLI, G.B.; KERR, D.; THOMAS, R.; TORLONE, E.; SOLAGAZAGNES, A.; VITACOLONNA, E.; SELAM, J.L.; HOME, P.D. Comparison of a multiple daily insulin injection regimen (Basal Once-Daily Glargine Plus Mealtime Lispro) and continuous subcutaneous insulin infusion (Lispro) in Type 1 Diabetes. A randomized open parallel multicenter study. Diabetes Care, v.32, n.7, p.1170-1176, 2009a.

BOLLI, G.B.; SONGINI, M.; TROVATI, M.; DEL PRATO, S.; GHIRLANDA, G.; CORDERA, R.; TREVISAN, R.; RICCARDI, G.; NOACCO, C. Lower fasting blood glucose, glucose variability and nocturnal hypoglycaemia with glargine vs NPH basal insulin in subjects with Type 1 diabetes. Nutr. Metab. Cardiovasc., v.19, n.8, p.571-579, $2009 \mathrm{~b}$

BRUNELLE, R.L.; LLEWELYN, J.; ANDERSON JR., J.H.; GALE, E.A.M.; KOIVISTO, V.A. Meta-analysis of the effect of insulin lispro on severe hypoglycemia in patients with type 1 diabetes. Diabetes Care, v.21, n.10, p.17261731, 1998.

BUCHER, H.C.; GUYATT, G.H.; GRIFFITH, L.E.; WALTER, S.D. The results of direct and indirect treatment comparisons in meta-analysis of randomized controlled trials. J. Clin. Epidemiol., v.50, n.6, p.683-691, 1997.

CIOFETTA, M.; LALLI, C.; DEL SINDACO, P.; TORLONE, E.; PAMPANELLI, S.; MAURO, L.; CHIARA, D.L.; BRUNETTI, P.; BOLLI, G.B. Contribution of postprandial versus interprandial blood glucose to $\mathrm{HbA}(1 \mathrm{c})$ in type 1 diabetes on physiologic intensive therapy with lispro insulin at mealtime. Diabetes Care, v.22, n.5, p.795-800, 1999.

DCCT. The effect of intensive treatment of diabetes on the development and progression of long term complications in insulin dependent diabetes mellitus. The diabetes control and complications trial research group. N. Engl. J. Med., v.329, n.14, p.977-986, 1993.

DE LEEUW, I.; VAGUE, P.; SELAM, J.L.; SKEIE, S.; LANG, H.; DRAEGER, E.; ELTE, J.W.F. Insulin detemir used in basal-bolus therapy in people with type 1 diabetes is associated with a lower risk of nocturnal hypoglycaemia and less weight gain over 12 months in comparison to NPH insulin. Diabetes Obes. Metab., v.7, n.1, p.73-82, 2005. 
DEVRIES, J.H.; LINDHOLM, A.; JACOBSEN, J.L.; HEINE, R.J.; HOME, P.D. A randomized trial of insulin aspart with intensified basal NPH insulin supplementation in people with type 1 diabetes. Diabetic Med., v.20, n.4, p.312-318, 2003.

FORST, T.; PFÜTZNER, A. Rapid-acting insulin analogues in type 1 diabetes without additional benefits? Diabetes Stoffwech. H., v.16, n.6, p.459-468, 2007.

FULCHER, G.R.; GILBERT, R.E.; YUE, D.K. Glargine is superior to neutral protamine Hagedorn for improving glycated haemoglobin and fasting blood glucose levels during intensive insulin therapy. Int. Med. J., v.35, n.9, p.536-542, 2005.

GARG, S.K.; CARMAIN, J.A.; BRADDY, K.C.; ANDERSON, J.H.; VIGNATI, L.; JENNINGS, M.K.; CHASE, H.P. Premeal insulin analogue insulin lispro vs Humulin $\hat{A} \circledast$ insulin treatment in young subjects with Type 1 diabetes. Diabetic Med., v.13, n.1, p.47-52, 1995.

GOUGH, S.C.L. A review of human and analogue insulin trials. Diabetes Res. Clin. Pr., v.17, n.1, p.1-15, 2007.

HELLER, S.; KOENEN, C.; BODE, B. Comparison of insulin detemir and insulin glargine in a basal-bolus regimen, with insulin aspart as the mealtime insulin, in patients with type 1 diabetes: a 52-week, multinational, randomized, openlabel, parallel-group, treat-to-target noninferiority trial. Clin. Ther, v.31, n.10, p.2086-2097, 2009.

HERMANSEN, K.; FONTAINE, P.; KUKOLJA, K.K.; PETERKOVA, V.; LETH, G.; GALL, M.A. Insulin analogues (insulin detemir and insulin aspart) versus traditional human insulins (NPH insulin and regular human insulin) in basal-bolus therapy for patients with type 1 diabetes. Diabetologia, v.47, n.4, p.622-629, 2004.

HIGGINS, J.P.T.; GREEN, S. (Eds.). Cochrane handbook for systematic reviews of interventions version 5.0.2. London: Wiley-Blackwell; The Cochrane Collaboration, 2009. $639 \mathrm{p}$.

HOME, P.; BARTLEY, P.; RUSSELL-JONES, D.; HANAIREBROUTIN, H.; HEEG, J. E.; ABRAMS, P.; LANDINOLSSON, M.; HYLLEBERG, B.; LANG, H.; DRAEGER, E. Insulin detemir offers improved glycemic control compared with NPH insulin in people with type 1 diabetes. A randomized clinical trial. Diabetes Care, v.27, n.5, p.1081-1087, 2004.
HOME, P.D. Rapid-acting insulin analogues: when randomized clinical trial results do not help. Diabetic Med., v.17, suppl. S2, p.6-8, 2000.

HOME, P.D.; HALLGREN, P.; USADEL, K.H.; SANE, T.; FABER, J.; GRILL, V.; FRIBERG, H.H. Pre-meal insulin aspart compared with pre-meal soluble human insulin in type 1 diabetes. Diabetes Res. Clin. Pr., v.71, n.2, p.131139, 2006.

HOME, P.D.; ROSSKAMP, R.; FORJANIC-KLAPPROTH, J.; DRESSLER, A. A randomized multicentre trial of insulin glargine compared with NPH insulin in people with type 1 diabetes. Diabetes Metab. Res. Rev., v.21, n.6, p.545-553, 2005.

JADAD, A. R.; MOORE, R.A.; CARROLL, D.; JENKINSON, C.; REYNOLDS, D.J.M.; GAVAGHAN, D.J.; MCQUAY, H.J. Assessing the quality of reports of randomized clinical trials: Is blinding necessary? Control Clin. Trials, v.17, n.1, p.1-12, 1996.

JANSSON, P.A.; EBELING, P.; SMITH, U.; CONGET, I.; COVES, M.J.; GOMIS, R.; LALLI, C.; DEL SINDACO, P.; BOLLI, G.B.; KOIVISTO, V.A. Improved glycemic control can be better maintained with insulin lispro than with human regular insulin. Diabetes Nutr. Metab., v.11, n.3, p.194-199, 1998.

MONAMI, M.; MARCHIONNI, N.; MANNUCCI, E. Longacting insulin analogues vs. NPH human insulin in type 1 diabetes. A meta-analysis. Diabetes Obes. Metab., v.11, n.4, p.372-378, 2009.

PIEBER, T.R.; BRUNNER, G.R.; SCHNEDL, W.J.; SCHATTENBERG, S.; KAUFMANN, P.; KREJS, G.J. Evaluation of a structured outpatient group education program for intensive insulin therapy. Diabetes Care, v. 18 , n.5, p.625-630, 1995.

PIEBER, T.R.; DRAEGER, E.; KRISTENSEN, A.; GRILL, V. Comparison of three multiple injection regimens for type 1 diabetes: morning plus dinner or bedtime administration of insulin detemir vs. morning plus bedtime NPH insulin. Diabetic Med., v.22, n.7, p.850-857, 2005.

PIEBER, T.R.; TREICHEL, H.C.; HOMPESCH, B.; PHILOTHEOU, A.; MORDHORST, L.; GALL, M.A.; ROBERTSON, L.I. Comparison of insulin detemir and insulin glargine in subjects with Type 1 diabetes using intensive insulin therapy. Diabetic Med., v.24, n.6, p.635$642,2007$. 
PLANK, J.; SIEBENHOFER, A.; BERGHOLD, A.; JEITLER, K.; HORVATH, K.; MRAK, P.; PIEBER, T.R. Systematic review and meta-analysis of short-acting insulin analogues in patients with diabetes mellitus. Arch. Intern. Med., v.165, n.12, p.1337-1344, 2005.

PORCELLATI, F.; ROSSETTI, P.; PAMPANELLI, S.; FANELLI, C.G.; TORLONE, E.; SCIONTI, L.; PERRIELLO, G.; BOLLI, G.B. Better long-term glycaemic control with the basal insulin glargine as compared with NPH in patients with type 1 diabetes mellitus given meal-time lispro insulin. Diabetic Med., v.21, n.11, p.1213-1220, 2004.

RASKIN, P.; GUTHRIE, R.A.; LEITER, L.; RIIS, A.; JOVANOVIC, L. Use of insulin aspart, a fast-acting insulin analog, as the mealtime insulin in the management of patients with type 1 diabetes. Diabetes Care, v.23, n.5, p.583-588, 2000.

RASKIN, P.; KLAFF, L.; BERGENSTAL, R.; HALLÉ, J.P.; DONLEY, D.; MECCA, T. A 16-week comparison of the novel insulin analog insulin glargine (HOE 901) and NPH human insulin used with insulin lispro in patients with type 1 diabetes. Diabetes Care, v.23, n.11, p.1666-1671, 2000.

RATNER, R.E.; HIRSCH, I.B.; NEIFING, J.L.; GARG, S.K.; MECCA, T.E.; WILSON, C.A. Less hypoglycemia with insulin glargine in intensive insulin therapy for type 1 diabetes. Diabetes Care, v.23, n.5, p.639-643, 2000.

ROSENSTOCK, J.; DAILEY, G.; MASSI-BENEDETTI, M.; FRITSCHE, A.; LIN, Z.; SALZMAN, A. Reduced hypoglycemia risk with insulin glargine: a meta-analysis comparing insulin glargine with human NPH insulin in type 2 diabetes. Diabetes Care, v.28, n.4, p.950-955, 2005.

ROSENSTOCK, J.; PARK, G.; ZIMMERMAN, J. Basal insulin glargine (HOE 901) versus NPH insulin in patients with type 1 diabetes on multiple daily insulin regimens. Diabetes Care, v.23, n.8, p.1137-1142, 2000.

RUSSELL-JONES, D.; SIMPSON, R.; HYLLEBERG, B.; DRAEGER, E.; BOLINDER, J. Effects of QD insulin detemir or neutral protamine hagedorn on blood glucose control in patients with type I diabetes mellitus using a basal-bolus regimen. Clin. Ther, v.26, n.5, p.724-736, 2004.
SIEBENHOFER, A.; PLANK, J.; BERGHOLD, A.; HORVATH, K.; SAWICKI, P.T.; BECK, P.; PIEBER, T.R.; KUNT, T.; VARDI, M.; JACOBSON, E.; NINI, A.; BITTERMAN, $\mathrm{H}$. Meta-analysis of short-acting insulin analogues in adult patients with type 1 diabetes: continuous subcutaneous insulin infusion versus injection therapy. Diabetologia, v.47, n.11, p.1895-1905, 2004.

SINGH, S.R.; AHMAD, F.; LAL, A.; YU, C.; BAI, Z. Efficacy and safety of insulin analogues for the manegement of diabetes mellitus: a meta-analysis. Can. Med. Assoc. J., v.180, n.4, p.385-397, 2009.

TAMAS, G.; MARRE, M.; ASTORGA, R.; DEDOV, I.; JACOBSEN, J.; LINDHOLM, A. Glycaemic control in type 1 diabetic patients using optimised insulin aspart or human insulin in a randomised multinational study. Diabetes Res. Clin. Pr., v.54, n.2, p.105-114, 2001.

UNITED KINGDOM PROSPECTIVE DIABETES STUDY. UK prospective diabetes study (UKPDS) group. Intensive blood-glucose control with sulphonylureas and insulin compared with conventional treatment and risk complications in patients with type 2 diabetes (UKDPS33). Lancet, v.352, n.9139, p.837-853, 1998.

VAGUE, P.; SELAM, J.L.; SKEIE, S.; DE LEEUW, I.; ELTE, J.W.; HAAHR, H.; KRISTENSEN, A.; DRAEGER, E. Insulin detemir is associated with more predictable glycemic control and reduced risk of hypoglycemia than NPH insulin in patients with type 1 diabetes on a basal-bolus regimen with premeal insulin aspart. Diabetes Care, v.26, n.3, p.590-596, 2003.

WARREN, E.; WEATHERLEY-JONES, E.; CHILCOTT, J.; BEVERLEY, C. Systematic review and economic evaluation of a long-acting insulin analogue, insulin glargine. Health Technol. Assess., v.8, n.45, p. 1-57, 2004.

WELLS, G.A.S.S.A.; CHEN, L.; KHAN, M.; COYLE, D. Indirect evidence: indirect treatment comparisons in meta-analysis. Ottawa: Canadian Agency for Drugs and Technologies in Health, 2009. 92 p.

Received for publication on $18^{\text {th }}$ June 2012 Accepted for publication on $13^{\text {th }}$ May 2013

SIEBENHOFER, A.; PLANK, J.; BERGHOLD, A.; NARATH, M.; GFRERER, R.; PIEBER, T.R. Short acting insulin analogues versus regular human insulin in patients with diabetes mellitus. Cochrane Database Syst. Rev., n.2, CD003287, 2004. 